\title{
PENGARUH TEMAN SEBAYA TERHADAP PRESTASI BELAJAR PESERTA DIDIK DALAM MATA PELAJARAN AQIDAH AKHLAK
}

Siti Ulfah Kuraesin, Wawan

IAILM Suryalaya

uululfah65@gmail.com,wawan070869@gmail.com

\begin{abstract}
Abstrack
This study aims to determine the condition of peers, learning achievement and to determine the influence of peers on student achievement. The research method used is descriptive method with a quantitative approach with a population of 102 people. Peers obtained an average value of 31.48 this figure is in the very good classification. Learning achievement obtained an average of 71.12 is in the very good classification. The rs price of 0.98 is classified as very high. The degree of determination between variable $(X)$ and variable (Y) is $96.04 \%$, indicating that an increase in learning achievement of $96.04 \%$ is determined by peers. The result of the calculation turns out that the tcount is 26.51 while the $t$ table based on the significance level $\alpha=0.15$ is obtained in the tist (0.85). (29) $=24.65$. With $t$ count $26.51 \geq t$ table 24.65 so that $H_{-} a$ is accepted and $H_{-} O$ is rejected. This shows that an increase in learning achievement of $96.04 \%$ is determined by peers, the remaining $3.96 \%$ is influenced by other factors.
\end{abstract}

Keywords: Peer Friends, Student Learning Achievements.

\begin{abstract}
Abstrak
Tujuan dari penelitian ini adalah untuk mengetahui kondisi teman sebaya, prestasi belajar dan untuk mengetahui pengaruh teman sebaya terhadap prestasi belajar peserta didik. Metode penelitian yang digunakan adalah metode deskriptif pendekatan kuantitatif dengan populasi 102 orang. Teman Sebaya diperoleh nilai rata-rata 31,48 angka tersebut berada pada klasifikasi sangat baik. Prestasi belajar diperoleh rata-rata 71,12 berada pada klasifikasi sangat baik. Harga rs sebesar 0,98 berada pada klasifikasi sangat tinggi. Derajat determinasi antara variabel (X) dengan variabel (Y) adalah 96,04 \% menunjukan bahwa peningkatan prestasi belajar sebesar 96,04\% ditentukan oleh teman sebaya. Hasil perhitungan ternyata $t_{\text {hitung }}$ sebesar 26,51 sedangkan $t_{\text {tabel }}$ berdasarkan taraf signifikasi $\alpha=0,15$ diperoleh dalam daftar t $(0,85)$. (29) $=24,65$. Dengan $t_{\text {hitung }} 26,51 \geq t_{\text {tabel }} 24,65$ sehingga $H_{a}$ diterima dan $H_{O}$ ditolak. Hal ini menunjukan bahwa peningkatan prestasi belajar sebesar 96,04\% ditentukan oleh teman sebaya, sisanya sebesar 3,96\% dipengaruhi oleh faktor lain.
\end{abstract}

Kata Kunci: Teman Sebaya, Prestasi Belajar Peserta Didik. 


\section{A. PENDAHULUAN}

Prestasi belajar peserta didik adalah hasil penilaian dari kegiatan belajar yang telah dilakukan dan merupakan bentuk perumusan akhir yang diberikan oleh guru untuk melihat sampai mana kemampuan peserta didik yang dinyatakan dalam bentuk simbol, angka, huruf maupun kalimat yang dapat mencerminkan hasil yang sudah dicapai. Namun untuk mendapatkan prestasi yang baik bukanlah hal yang mudah, tetapi membutuhkan usaha yang optimal.

Menurut Slameto (2015.54) Secara garis besar, faktor-faktor yang mempengaruhi prestasi belajar peserta didik dibedakan menjadi dua yaitu faktor internal dan faktor eksternal. Faktor penting yang mempengaruhi prestasi belajar salah satunya adalah teman sebaya. Teman sebaya merupakan terjadinya suatu interaksi yang intensif dan cukup teratur dengan orang-orang yang mempunyai kesamaan dalam usia dan status, yang memberikan dampak atau pengaruh positif maupun negatif yang dikenakan interaksi didalamnya.

Prestasi belajar peserta didik di Madrasah Diniah Takmiliyah (MDT) Pondok Pesantren Nurul Falah Kecamatan Pagerageung belum seluruhnya mencapai hasil yang optimal. Berdasarkan observasi yang telah dilakukan, ternyata kondisi teman sebayanya lebih mengarahkan pada hal-hal yang bersifat negatif. Seperti, teman sebaya tidak saling mengingatkan dalam hal belajar, bercanda pada saat pembelajaran berlangsung, banyaknya peserta didik yang jarang mengerjakan tugas dari gurunya dan peserta didik lebih asyik ngobrol dengan teman sebelahnya daripada mendengarkan penjelasan guru. Kondisi teman sebaya tersebut tentu saja menjadi penyebab rendahnya prestasi belajar peserta didik karena peran serta dukungan teman sebaya sangatlah penting bagi perkembangan peserta didik.

Uraian di atas menjadi dasar merumuskan masalah di atas, maka yang dapat diambil dalam penelitian ini adalah :

a. Bagaimana kondisi teman sebaya di Madrasah Diniah Takmiliyah (MDT) Pondok Pesantren Nurul Falah Kecamatan Pagerageung?

b. Bagaimana prestasi belajar peserta didik di Madrasah Diniah Takmiliyah (MDT) Pondok Pesantren Nurul Falah Kecamatan Pagerageung ?

c. Bagaimana pengaruh teman sebaya terhadap prestasi belajar peserta didik di Madrasah Diniah Takmiliyah (MDT) Pondok Pesantren Nurul Falah Kecamatan Pagerageung ?

\section{Teman Sebaya}

Menurut Umar (2005: 181) "Kelompok sebaya adalah suatu kelompok yang terdiri dari orang yang bersamaan usianya". Menurut Slavin (2008:98) mengungkapkan bahwa "Teman sebaya merupakan suatu interaksi dengan orangorang yang mempunyai kesamaan dalam usia dan status".

Indikator teman sebaya terdiri dari :

a. Interaksi sosial yang di lakukan

b. Tempat pengganti keluarga

c. Memberi pengalaman yang tidak didapat dalam keluarga 
d. Partner belajar yang baik (Umar, 2005:181).

2. Prestasi Belajar

Menurut Syaiful Bahri Djamarah (2012:19) Prestasi belajar adalah sebuah kalimat yang terdiri dari dua kata yaitu "prestasi" dan "belajar" . Prestasi adalah hasil dari suatu kegiatan yang telah dikerjakan atau diciptakan. Sedangkan belajar adalah suatu aktivitas sadar akan suatu tujuan.

Menurut Sumadi (2002:297) "Prestasi belajar merupakan bentuk perumusan akhir yang diberikan oleh guru terkait dengan kemajuan atau prestasi belajar siswa selama waktu tertentu". Menurut Sutratinah (2001:43) bahwa "Prestasi belajar adalah penilaian hasil usaha kegiatan yang dinyatakan dalam bentuk simbol, angka, huruf maupun kalimat yang dapat mencerminkan hasil yang sudah dicapai oleh setiap anak dalam periode tertentu".

3. Pengaruh Teman Sebaya Terhadap Prestasi Belajar

Selain lingkungan keluarga yang ikut mempengaruhi prestasi belajar seorang individu jika individu tersebut telah berinteraksi dengan individu lain adalah teman sebaya. Teman sebaya merupakan lingkungan bergaul seorang anak melalui interaksi dengan teman sebaya, individu akan berkenalan dan mulai bergaul dengan temantemannya dengan pola perilaku yang berbeda-beda, sehingga melalui interaksi inilah masing-masing individu akan saling memahami keinginan-keinginan dan tidak jarang individu akan membentuk kelompok-kelompok jika perilaku teman-temannya tersebut telah dirasa cocok.

Pergaulan teman sebaya dapat mempengaruhi prestasi belajar. Pengaruh tersebut dapat berupa pengaruh positif dan dapat pula berupa pengaruh negatif. Pengaruh positif yang dimaksud adalah ketika individu bersama teman-teman sebayanya melakukan aktivitas yang bermanfaat seperti membentuk kelompok belajar. Sedangkan pengaruh negatif yang di maksudkan adalah dapat berupa pelanggaran terhadap lingkungan sekolah/ berupa pelanggaran terhadap aturan sekolah.

Sebagaimana yang diungkapkan oleh Hurlock dalam Mu'tadin (2002: 22) bahwa melalui hubungan teman sebaya anak berfikir mandiri, mengambil keputusan sendiri, menerima bahkan menolak pandangan dan nilai yang berasal dari keluarga dan mempelajari pola perilaku yang diterima didalam kelompoknya.

\section{B. METODE}

Sesuai dengan permasalahan yang diteliti maka metode yang digunakan dalam penelitian ini adalah metode deskriptif dengan pendekatan kuantitatif. Penelitian ini memiliki dua variabel, yaitu variabel independen (bebas) dalam penelitian ini adalah (X) teman sebaya dan variabel dependen (terikat) dalam penelitian ini adalah (Y) prestasi belajar peserta didik. Populasi dalam penelitian ini adalah seluruh peserta didik Madrasah Diniah Takmiliyah Nurul Falah Desa SukapadaKecamatan Pagerageung Kabupaten Tasikmalaya yang berjumlah102 orang. Dalam penelitian ini teknik 
pengambilan sampel yang digunakan adalah teknik proporsional sampling. Teknik ini digunakan karena keterbatasan waktu, biaya dan tenaga. maka akan diambil sampel dari kelas IV (empat) sampai kelas VI (enam) sebanyak 31 peserta didik. Instrumen penelitian yang digunakan adalah pedoman observasi, pedoman wawancara dan angket. Sedangkan teknik pengumpulan data yang digunakan adalah observasi, wawancara dan angket. Teknik analisis data yang digunakan adalah rata-rata hitung $\dot{i}$ ) untuk analisis variabel dan rank spearman (rs) untuk korelasi antar variabel (pengaruh X terhadap Y). Dengan kriteria :

Jika $\mathrm{t}_{\text {hitung }} \geq \mathrm{t}_{\text {tabel }}$ maka $\mathrm{H}_{\mathrm{a}}$ diterima dan $\mathrm{H}_{\mathrm{o}}$ ditolak

Jika $\mathrm{t}_{\text {hitung }}<_{\mathrm{t} \text { tabel }}$ maka $\mathrm{H}_{a}$ ditolak dan $\mathrm{H}_{\mathrm{o}}$ diterima

\section{HASIL DAN PEMBAHASAN}

\section{Hasil variable Teman Sebaya}

Dari angket yang di sebarkan dengan skala pengukuran ordinal sebanyak 10 item dan 5 option dengan $\mathrm{n}=31$ diperoleh skor untuk variabel $(\mathrm{X})$ sebagai berikut :

$\begin{array}{lllllllllll}30 & 30 & 21 & 37 & 25 & 26 & 36 & 33 & 33 & 44 & 36 \\ 22 & 36 & 25 & 28 & 30 & 41 & 22 & 41 & 36 & 33 & 32 \\ 28 & 41 & 37 & 25 & 27 & 29 & 30 & 33 & 32 & & \end{array}$

Untuk proses selanjutnya menghitung rata-rata $(\bar{X})$ variabel teman sebaya $(\mathrm{X})$ $\bar{X}=\frac{\sum f \cdot x i}{\sum f}$

$$
\begin{aligned}
& =\frac{976}{31} \\
& =31,48
\end{aligned}
$$

Untuk proses selanjutnya yaitu menghitung simpangan rata-rata (SR) untuk variabel X

$$
\begin{aligned}
S R=\frac{\sum i x_{I-i X / f i} i}{\sum N} i & \\
& =\frac{77,96}{31} \\
& =2,51
\end{aligned}
$$

Berdasarkan rata-rata dan simpangan rata-rata (SR) diatas dibuat skala penafsiran sebagai berikut :

\begin{tabular}{|l|}
\hline Skor Min +4 SR \\
Sangat Baik \\
Skor Min +3 SR \\
Baik \\
Skor Min +2 SR \\
Cukup \\
Skor Min + 1SR \\
Kurang \\
\hline
\end{tabular}


Jadi penghitungannya sebagai berikut :

$$
\begin{aligned}
& 21+4(2,51)=31,04 \\
& 21+3(2,51)=28,53 \\
& 21+2(2,51)=26,02 \\
& 21+1(2,51)=23,51
\end{aligned}
$$

Hasil perhitungan dan analisis terhadap rata-rata hitung $(\bar{X})$ dan simpangan rata-rata (SR) untuk teman sebaya adalah 31,48 angka tersebut diatas skala penafsiran 31,04 berada pada klasifikasi sangat baik.

\section{Hasil variable Prestasi Belajar Peserta Didik}

Nilai raport yang diperoleh sebagai berikut :

$\begin{array}{llllllllll}65 & 70 & 55 & 80 & 60 & 65 & 75 & 70 & 75 & 90 \\ 75 & 60 & 80 & 60 & 65 & 70 & 85 & 60 & 85 & 75 \\ 75 & 70 & 65 & 90 & 80 & 60 & 65 & 65 & 70 & 75\end{array}$

70

Untuk selanjutnya menghitung rata-rata hitung dengan menggunakan rumus sebagai berikut :

$$
\begin{aligned}
\bar{X}=\frac{\sum f \cdot x i}{\sum f} & \\
& =\frac{2205}{31} \\
& =71,12
\end{aligned}
$$

Selanjutnya, menghitung simpangan rata-rata (SR)

Untuk menghitung SR digunakan rumus sebagai berikut :

$$
\begin{aligned}
S R=\frac{\sum i x_{I-i X / f i}}{\sum N} i & \\
& =\frac{80}{31} \\
& =2,58
\end{aligned}
$$

Berdasarkan rata-rata dan simpangan rata-rata (SR) diatas dibuat skala penafsiran dengan penghitungannya sebagai berikut :

$$
\begin{aligned}
& 55+4(2,58)=65,32 \\
& 55+3(2,58)=62,74 \\
& 55+2(2,58)=60,16 \\
& 55+1(2,58)=57,58
\end{aligned}
$$

Berdasarkan skala penafsiran diatas, rata-rata hitung untuk variabel $\mathrm{Y}$ adalah 71,12 diatas skala penafsiran 65,32. Hal ini menunjukan bahwa prestasi belajar peserta didik berada pada kondisi sangat baik.

\section{Pengaruh Teman Sebaya terhada Prestasi Belajar Peserta Didik}

a Menghitung Korelasi Antara Variabel X dan Variabel Y 
$\mathrm{r}_{\mathrm{s}}=1-\frac{6 \sum d i^{2}}{N^{3}-N}$

Dimana: $\mathrm{n}=$ banyaknya responden/ sampel

$d i^{2}=$ Kuadrat perbedaan ranking $\mathrm{X}$ dan $\mathrm{Y}$

Oleh karena itu maka:

$$
\begin{aligned}
& \mathrm{r}_{\mathrm{s}}=1-\frac{6 \sum d i^{2}}{N^{3}-N} \\
& \mathrm{r}_{\mathrm{s}}=1-\frac{6(98)}{31^{3}-31} \\
& \mathrm{r}_{\mathrm{s}}=1-\frac{588}{29,791-31} \\
& \mathrm{r}_{\mathrm{s}}=1-\frac{588}{29,760} \\
& \mathrm{r}_{\mathrm{s}}=1-0,0197 \\
& \mathrm{r}_{\mathrm{s}}=0,98
\end{aligned}
$$

Untuk kepentingan penafsiran digunakan klasifikasi tentang batas-batas puntuk rs sebagai berikut:

\begin{tabular}{|c|c|c|}
\hline $0,81-1,00$ & Very High & Sangat Tinggi \\
$0,61-0,80$ & High & Tinggi \\
$0,41-0,60$ & Moderate & Cukup \\
$0,21-0,40$ & Low & Sedang \\
$0,00-0,20$ & Very Low & Rendah \\
& & Sangat Rendah \\
\hline
\end{tabular}

Berdasarkan harga rs sebesar 0,98 berada pada klasifikasi sangat tinggi. Hal ini berarti teman sebaya dalam meningkatkan prestasi belajar peserta didik sangat penting serta teman sebaya mempunyai korelasi yang tinggi dengan prestasi belajar di Madrasah Diniah Takmiliyah Nurul Falah.

b Menentukan Derajat Determinasi

Untuk menentukan derajat determinasi digunakan rumus sebagai berikut:

$$
\begin{aligned}
& D=\mathrm{rs}^{2} \times 100 \% \\
& D=0,98^{2} \times 100 \% \\
& D=0,9604 \times 100 \% \\
& D=96,04 \%
\end{aligned}
$$

Derajat determinasi teman sebaya terhadap prestasi belajar peserta didik adalah sebesar 96,04 \%. Hal ini menunjukan bahwa peningkatan prestasi belajar sebesar 96,04\% ditentukan oleh teman sebaya, dan sisanya sebesar 3,96\% dipengaruhi oleh faktor lain.

c Uji Signifikansi/ Uji Hipotesis

Adapun hipotesis kerja yang penulis rumuskan adalah:

Ha: Teman sebaya diduga berpengaruh secara signifikan terhadap prestasi belajar 
Ho: Teman sebaya diduga tidak berpengaruh secara signifikan terhadap prestasi belajar

Maka untuk kepentingan uji signifikansi koefisien korelasi (rs) atau uji hipotesis digunakan rumus sebagai berikut:

$\mathrm{t}_{\text {hitung }}=\mathrm{rs} \sqrt{\frac{N-2}{1-r s^{2}}}$

Dimana :

$\mathrm{t}=$ Distribusi / statistik $\mathrm{t}$

rs= Harga rs yang di peroleh

$\mathrm{n}=$ Ukuran sampel

$1=$ Bilangan konstanta

Maka:

$\mathrm{t}=\mathrm{rs} \sqrt{\frac{N-2}{1-r s^{2}}}$

$\mathrm{t}=0,98 \sqrt{\frac{31-2}{1-0,98^{2}}}$

$\mathrm{t}=0,98 \sqrt{\frac{29}{0,0396}}$

$\mathrm{t}=0,98 \sqrt{732,32}$

$\mathrm{t}=0,98(27,06)$

$\mathrm{t}=26,51$

$$
\begin{aligned}
\mathrm{t}_{\text {tabel }} & =\mathrm{t}(1-a)(\mathrm{dk}) \\
& =\mathrm{t}(1-0,15)(\mathrm{n}-2) \\
& =\mathrm{t}(0,85)(31-2) \\
& =\mathrm{t}(0,85)(29) \\
& =24,65
\end{aligned}
$$

Setelah dilakukan perhitungan ternyata $t_{\text {hitung }}$ sebesar 26,51 sedangkan $t_{\text {tabel }}$ berdasarkan taraf berdasarkan taraf signifikasi $a=0,15$ diperoleh dalam daftar $\mathrm{t}$ ( 0,85).(29) $=24,65$. Dengan $t_{\text {hitung }} 26,51 \geq t_{\text {tabel }} 24,65$ sehingga Ha diterima dan Ho ditolak. Hal ini berarti bahwa hipotesis yang menyatakan terdapat pengaruh teman sebaya terhadap prestasi belajar peserta didik dapat diterima.

Dengan demikian bahwa teman sebaya berpengaruh baik terhadap prestasi belajar peserta didik di Madrasah Diniah Takmiliyah Nurul Falah Kampung Lusian Desa Sukapada Kecamatan Pagerageung Kabupaten Tasikmalaya.

Dari hasil penelitian dan analisis data yang diperoleh dapat dijabarkan sebagai berikut: 
a. Teman Sebaya

Berdasarkan hasil analisis, maka dapat dikatakan bahwa faktor teman sebaya mempunyai peran terhadap prestasi belajar peserta didik. Hasil analisis diperoleh nilai rata-rata hitung untuk variabel $\mathrm{X}$ adalah 31,48 nilai tersebut diatas skala penafsiran 31,04 berada pada klasifikasi sangat tinggi. Hal ini menunjukan bahwa keberadaan teman sebaya berada pada klasifikasi sangat baik berdasarkan indikator penelitian: interaksi sosial yang dilakukan, tempat pengganti keluarga, memberi pengalaman yang tidak didapat dalam keluarga dan partner belajar yang baik.

b. Prestasi Belajar Peserta Didik

Berdasarkan hasil pengolahan data prestasi belajar dapat disimpulkan bahwa rata-rata hitung untuk variabel $\mathrm{Y}$ adalah 71,12 diatas skala penafsiran 65,32. Hal ini menunjukan bahwa prestasi belajar peserta didik berada pada kondisi sangat baik berdasarkan indikator aspek kognitif, afektif dan psikomotor.

c. Pengaruh Teman Sebaya terhadap Prestasi Belajar Peserta Didik

Untuk besarnya pengaruh teman sebaya terhadap peserta didik dalam proses belajar di madrasah, berdasarkan harga rs diperoleh nilai sebesar 0,98 apabila ditafsirkan pada skala pengukuran batas-batas $\rho$ diperoleh nilai pada klasifikasi sangat tinggi. Hal ini membuktikan bahwa teman sebaya dalam meningkatkan prestasi belajar peserta didik sangat tinggi, pengaruh teman sebaya ini memegang peran yang sangat penting dalam meningkatkan prestasi belajar. Untuk derajat determinasi antara variabel $\mathrm{X}$ dengan variabel $\mathrm{Y}$ adalah sebesar 96,04\% menunjukan bahwa peningkatan prestasi belajar sebesar 96,04\% ditentukan oleh teman sebaya sisanya sebesar $3,96 \%$ dipengaruhi oleh faktor lain.Hasil pengujian hipotesis dengan uji $t$ ternyata $t_{\text {hitung }} 26,51$ sedangkan $t_{\text {tabel }}$ berdasarkan taraf signifikasi $\alpha=0,15$.Diperoleh dalam daftar $t(0,85) .(29)=24,65$. Dengan $t_{\text {hitung }} 26,51 \geq t_{\text {tabel }}$ 24,65 sehingga Ha diterima dan Ho ditolak.Hasil kategorisasi tersebut menunjukan teman sebaya secara umum termasuk kategori tinggi, dimana artinya teman sebaya mempunyai peran dalam meningkatkan prestasi belajar peserta didik, hasil penelitian ini diperkuat dengan penelitian yang dilakukan Ridwan (2012:32) yang menyebutkan bahwa peserta didik yang melaksanakan kegiatan belajar dengan para temannya secara psikologis lebih kecil kecenderungan untuk tidak berprestasi. Kebutuhan psikologis ini akan di dapatkan peserta didik dari temannya yang lebih menguasai materi pembelajaran

\section{SIMPULAN}

Berdasarkan pada hasil analisis maka penulis dapat menarik kesimpulan sebagai berikut:

1. Teman sebaya di Madrasah Diniah Takmiliyah Nurul Falah setelah dilakukan penelitian dan uji statistik diperoleh nilai rata-rataan 31,48, angka tersebut berada diatas skala penafsiran 31,04 pada klasifikasi sangat baik. Dengan 
demikian teman sebaya merupakan salah satu indikator dalam memotivasi peserta didik supaya peserta didik dapat belajar secara aktif.

2. Berdasarkan hasil pengolahan data prestasi belajar dapat disimpulkan bahwa rataan untuk variabel (Y) adalah 71,12 diatas skala penafsiran 65,32 berada pada klasifikasi sangat baik. Hal ini menunjukan bahwa prestasi belajar peserta didik berada pada kondisi sangat baik.

3. Pengaruh teman sebaya berdasarkan harga rs diperoleh nilai sebesar 0,98 berada pada klasifikasi sangat tinggi. Hal ini berarti teman sebaya dalam meningkatkan prestasi belajar peserta didik memegang peran yang sangat penting. Derajat determinasi antara variabel (X) dengan variabel (Y) adalah 96,04\%. Hal ini menunjukan bahwa peningkatan prestasi belajar sebesar 96,04\% ditentukan oleh teman sebaya, sisanya sebesar 3,96\% dipengaruhi oleh faktor lain. Hasil perhitungan ternyata $t_{\text {hitung }}$ sebesar 26,51 sedangkan $t_{\text {tabel }}$ berdasarkan taraf signifikasi $\alpha=0,15$.Diperoleh dalam daftar $\mathrm{t}(0,85) .(29)=24,65$. Dengan $t_{\text {hitung }}$ $26,51 \geq \mathrm{t}_{\text {tabel }} 24,65$ sehingga Ha diterima dan Ho ditolak.

\section{DAFTAR PUSTAKA}

Ahmadi, Abu dan Widodo Supriyono. (2004). Psikologi Belajar. Jakarta: PT Rineka Cipta. Ahmadi, Abu. (2007) Psikologi Perkembangan. Jakarta: Rineka Cipta

Alghazali. (2005). Ihya Ulumiddin. Bandung: Pustaka.

Aunurrahman. (2010). Belajar dan Pembelajaran. Bandung: Alfabeta

Baharuddin, Esa Nur Wahyudi. (2009). Teori Belajar dan Pembelajaran. Jogjakarta: ArRuzz Media

Danim, Sudarwan. (2013). Perkembangan Peserta Didik: Alfabeta

Depdiknas (2003) Undang-undang Sistem Pendidikan Nasional

Djamarah, Syaiful Bahri. (2012). Prestasi Belajar dan Kompetensi Guru. Surabaya: Usaha Nasional.

Fakultas Tarbiyah IAILM. (2012). Pedoman Penulisan Skripsi.

Hurlock, Elizabeth. (2002). Perkembangan Anak. Jakarta : Erlangga

Itsnaini, Nurhikmah Jufri. (2017). Pertemanan Persektif Islam. Tesis Magister Ilmu AlQur'an dan Tafsir (Tidak dipublikasikan). Makasar : Program Pascasarjana UIN Alauddin Makasar.

Munggaran, Nita Anjung dan Neneng Hartini. (2009). Meraih Sukses Berbahasa Indonesia. Bandung: CV Wahana Karya Grafika.

Ngalim, Purwanto. (2006.) Psikologi Pendidikan. Bandung: PT Remaja Rosdakarya

Partowisastro, Koestoer. (1983). Dinamika Psikologi Sosial .Jakarta: Erlangga

Purwanto. (2010). Evaluasi Hasil Belajar. Yogyakarta: Pustaka Belajar

Rahayu, Septiana. (2017). Pengaruh lingkungan Teman Sebaya dan Motivasi Belajar terhadap Hasil Belajar Siswa Kelas X IIS SMA Negeri 1 Sewon. Skripsi Sarjana (Tidak dipublikasikan). Yogyakarta: Fakultas Ekonomi

Slameto. (2013). Belajar dan Faktor-faktor yang Mempengaruhinya. Jakarta: PT Rineka Cipta. 
Sugihartono, dkk. (2007). Psikologi Pendidikan.Yogyakarta: UNY Press

Slameto. (2013). Belajar dan Faktor-faktor yang Mempengaruhinya. Jakarta: PT Rineka Cipta

Slavin, Robert E. (2008) Psikologi Pendidikan Teori dan Praktik. Jakarta: PT Indeks.

Sudjana, N. (2005.) Penelitian Hasil Belajar Mengajar. Bandung: PT Remaja Rosdikarya

Sugihartono, dkk. (2007). Psikologi Pendidikan. Yogyakarta: UNY Press.

Sugiyono. (2010). Statistika Untuk Penelitian. Bandung: Alfabeta

Suharsimi, Arikunto. (2003). Manajemen Pengajaran Secara Manusiawi. Jakarta: Rineka Cipta.

Susilowati, Andari. (2009). Pengaruh Motivasi, Minat Dan Lingkungan Teman Sebaya terhadap Prestasi Belajar Mahasiswa Akafarma Sunan Giri Ponorogo. Skripsi: Universitas Surakarta.

Syah, Muhibbin (2008). Psikologi Pendidikan dengan Pendekatan Baru. Bandung: Remaja Rosdakarya.

Syaodih, Nana Sukmadinata. (2009.) Landasan Psikologis Proses Pendidikan. Bandung: PT Remaja Rosdakarya

Tafsir, Ahmad. (2007). Ilmu Pendidikan Islam dalam Perspektif Islam. Bandung: PT Remaja Rosdakarya

Tirtarahardja Umar, La Sulo. (2005). Pengantar Pendidikan. Jakarta: Rineka Cipta

Umar, Husein. (2005). Metode Penelitian. Jakarta: Selemba Empat.

Vembriarto. (2003). Sosiologi Pendidikan. Jakarta: PT Gramedia Widia Sarana.

Wawan. (2015). Desain Penelitian Kuantitatif. Tasikmalaya: Latifah Press.

Wawan. (tanpa tahun). Pengantar Statistika pendidikan. Tasikmalaya: Latifah Press. 